\title{
Impact of the Corona Pandemic on Household Welfare in Cameroon
}

\author{
Joachem Meh BIN ${ }^{1}$, Moses A. Ofeh ${ }^{2} \&$ Sergeo Beng CHE $^{3}$ \\ ${ }^{1}$ Faculty of Economics and Management, University of Bamenda, Cameroon \\ ${ }^{2}$ Higher Teacher Training College Bambili, University of Bamenda, Post Box 39 Bambili, Cameroon \\ ${ }^{3}$ Faculty of Economics and Management, University of Yaoundé II-Soa, Cameroon \\ Correspondence: Moses A. Ofeh, Higher Teacher Training College Bambili, Post Box 39 Bambili, Cameroon. \\ Phone: 237-677-879-520. E-mail: ofeh2002@yahoo.fr
}

Received: July 31, 2020; Accepted: August 30, 2020; Published: September 4, 2020

The research is financed by (Personal savings).

\begin{abstract}
The objective of this study was to examine the effect of the Corona Virus Disease (COVID-19) on household welfare in Cameroon. This was done using data from a survey of 264 households in Cameroon in 2020. A linear regression model and Heckman sample correction bias were used and the results showed that COVID-19 reduces household welfare in Cameroon. These findings have implications of reducing the impact of COVID-19 on household welfare if households should develop new sources of income and food strategies by engaging more on agricultural activities and government can take a strategy of allocating grants either by reducing the cost of necessities (water, electricity, foodstuff, and housing). The triple helix approach where government, institutions of technology, and businesses should develop a vaccine for the pandemic to bring back economic life to normal.
\end{abstract}

Keywords: COVID-19, Household welfare, Linear regression model, Heckman sample selection bias, Cameroon

\section{Introduction}

As we enter the sixth month of the COVID- 2019 pandemic (WHO, 2019) which is affecting about 203 countries and territories around the world and two international conveyances (the Diamond Princess cruise ship harbored in Yokohama, Japan, and the Holland America's MS Zaandam cruise ship), no effective COVID-2019 preventive vaccine has been found (China's NHC, 2019). As the numbers of those infected by the pandemic continuously augment from 721330 on the $29 / 03 / 2020$ to 871,985 on the $31 / 03 / 2020$ and the number of deaths from 33956 to 43,261 showing a $21.51 \%$ increase (China's NHC, 2019), these statistics make the effective demand for such a vaccine necessary and urgent.

In current times, the entire world has been gripped by the emergence of a new pandemic (Coronavirus disease) which has not only become a global health concern but has transformed from a health crisis to a seemingly economic crisis in which no country is left untouched. The COVID-19 disease which many say break-out in China in late 2019 has at present claimed the lives of over 33,257 people, with about 697,244 cases already affected throughout the world (WHO, March 31, 2020).

According to some health scientists, Coronavirus is from a family of viruses that can cause illnesses such as the common cold, severe acute respiratory syndrome (SARS), and Middle East respiratory syndrome (MERS). Besides, Signs and symptoms may appear between 2 to 14 days after exposure and can include: fever, cough, difficulty breathing, tiredness, aches, runny nose, and sore throat, just to name a few (WHO, March 2020).

Due to its severity and the fast possibility of public contamination, WHO in March 2020 declared a global pandemic and issued recommendations for preventing and treating the illness. Amongst them are; frequently washing of hands (to kill hands-infected viruses), social distancing (to avoid sneezes that may spray small liquid droplets), avoiding the touching MEN (mouth, eyes and nose), so as to avoid the transfer of the virus to your mouth, eyes and nose, practicing of respiratory hygiene (protect the people around), seeking medical care early enough if any of the symptoms is detected (to quickly verify and give directives to the right health facility) and above all to stay home and stay safe as preventive measures and the creation of Centers for Disease Control and Prevention, and wearing of a mask to handle already infected cases (WHO, March 2020). 
This epidemic has brought not only the risk of death from a viral infection but also unbearable economic pressure. Just some few weeks ago, COVID-19 seemed to be essentially a Chinese problem and China was dealing with it forcefully but today times have changed, the disease has rapidly spread human suffering throughout the world. Come to think of it, the world economy that was getting well on the way to a nice recovery just some few months ago; trade was seen as "not so bad", growth projections were rosy and financial markets were cheery is today and in the nearest future likely to slip into a global recession according to an IMF statement made on March 4, 2020 (OECD, 2020).

It is therefore clear that the persistence of COVID-19 would have untold consequences on the world's economy. Unlike a healthy person who catches seasonal flu and suffers a nasty but short-lived discomfort, the consequences here will rather be felt in the long run, although a short-and-sharp crisis is still more likely possible. This pandemic has already and almost outweighed previous post-war pandemics like the Severe Acute Respiratory Syndrome (SARS) of 2002; 2009 Avian flu (N1H1) of 2009; Middle East Respiratory Syndrome (MERS) of 2012; Ebola Virus Disease (EVD) of 2014, not only by the larger number of cases both infected and death registered so far. Economically speaking the pandemic has hit hard the world largest economies (USA, China, Japan, Germany, Britain, France, and Italy). The rest of the world has simply suffered the contagion effect of these economies which sneezes and causes cold worldwide (Baldwin and Weder di Mauro, 2020).

The effects of this pandemic on the global economy can be viewed from two dimensions; on the supply or manufacturing side and the demand or consumption side. On the supply side, global production has been disrupted since workers are encouraged to stay at home as a preventive measure. Also, due to fear of contagion shocks, manufacturing sectors in less-affected nations find it harder and/or more expensive to acquire the necessary imported industrial inputs from the hard-hit nations and especially with the closing of borders by most countries. As if that is not enough, the financial market has been highly hit thereby causing delays in investments by firms and other private investors. Again, the closure of borders, schools, and travel bans directly reduces productivity and temporarily lead to drops in employment. The largest nations in the global supply chain (China, Japan, and Korea) are amongst the hardest hit nations and hence the shocks will be strongly felt worldwide employing contagion (Baldwin and Weder di Mauro, 2020).

On the demand side, two shocks are worth distinguishing: practical and psychological. Practical in the sense that, some consumers are quarantined or prevented from going to demand whatever they desire to consume. So, their demand disappears from the market. Likewise, some home delivery services are suspended, so goods and consumers are coming together less frequently. This has made trade volumes to collapse between nations and also because firms have postponed purchases and delayed investments on wait-and-see tactics. On a psychological plane, consumers and firms have tended to embrace a wait-and-see attitude because of the uncertainty of COVID19 (Baldwin and Weder di Mauro, 2020).

Since Africa is highly interconnected with the rest of the world, it has equally got to suffer some setbacks due to direct transmission of not only the virus but also economic challenges. This is seen through trade links with China and Europe, or through trade links between China, Europe and the rest of the world, which leads to a decline in remittances and tourism, FDI flows, capital flight and domestic financial market tightening, disruption of global supply chains being a drop in value creation, demand-side shocks: Oil, tourism, remittances, slowdown in investment hence job losses. For oil exporters, revenue losses of up to USD 65 billion, inflationary pressures due to supply-side shortages (Food and Pharma), unanticipated increases in health spending of up to USD 10.6 billion, revenue losses could lead to unsustainable debt, and others (UNECA, March 13, 2020).

In the midst of all, Cameroon is not indifferent, as per the declaration of the minister of public health, over 509 cases have been tested positive and about 8 deaths recorded and 17 recovered (MINSANTE, April 3, 2020). The disease has equally eaten deep into the nation to the extent that some stakeholders are proposing a shut-down of the economy, but shutting down the economy is not like shutting down a lighted bulb. It's more like shutting down a nuclear reactor. You need to do it slowly and carefully with precautions on the outcomes of the household. This is the reason why we want to examine the economic impact of this disease on the welfare of Cameroonian households.

In Cameroon, the state of welfare of a household is already poor and the presence of this pandemic has only come to make a bad situation worse. For example, out of an estimated 21 million inhabitants, at least 8 million Cameroonians live below the poverty line of 931 FCFA per day (INS, 2014).

In order to build a picture of relative wellbeing, we take a set of commonly used criteria for needs, including (1) poverty (percent of the population living on less than $738 \mathrm{CFAF} /$ day); (2) education (percent of the population who were schooling before the closure of educational establishments); (3) Hygiene (number of hand-washing points); 
(4) mortality rate (deaths per 1000 live births;); (5) unemployment (ILO definition; percent of the population in relevant age group); (6) access to clean toilets (percent of the population); and (7) medical centers (number of the hospital treating COVID-19 and isolation centers).

Since we are not Doctors to propose an englobing treatment to this pandemic, as economists we ask the key question; what are the impacts of COVID-19 on the welfare of Cameroonian households? However, it will not be impossible for us to look at how far the economic damage spread? And, above all, what the government can do to dilute the impasse. The evolution of the disease is highly uncertain which makes it difficult for policymakers to formulate an appropriate macroeconomic policy response. In order to better understand possible economic outcomes, this paper explores and proposes.

Taking note of the introduction, the rest of the article is divided into four more sections. The second section presents a review of the state of the literature on the macroeconomic causes of diseases. The third sketches the methodological strategy. The fourth discusses the results. The fifth concludes and suggests some economic policy recommendations.

\section{Review of Literature}

\subsection{Conceptual Framework}

The COVID-19 pandemic (Note 1) broke out in December 2019 in Wuhan, China. This disease according to medics is caused by a novel coronavirus contracted from inanimate surfaces that causes severe cases of pneumonia. Severe acute respiratory syndrome SARS-COV as it has been dubbed broke out in Asia in 2003 and more than 8,000 people were infected, with $10 \%$ mortality. It has been argued in some quarters that the cause of this pandemic is yet unknown, which accounts for the absence of effective treatment and/or vaccination. But like the American economist and psychologist Frank Knight (1885-1972) said; "there are things we know that we don't know", we call them "the known unknowns" and there are "things we do not yet know that we do not know", that we call the "unknown unknowns". Indeed, this is to say coronavirus had been previously noted, that is why the cause is called new coronavirus and the syndrome-SARS-COV-2. Whatever the cause, it is important to note as earlier mentioned that the outbreak of a health crisis has seemingly transformed into an economic threat.

This evolution of the disease is highly uncertain and makes it difficult for policymakers to formulate an appropriate macroeconomic policy response. According to the WHO statistics, at least 976 people die daily in the world and 21 of which are from Africa, and at least 86108 get infected every day throughout the globe likewise 1098 in Africa (WHO, May 4, 2020).

Table A. Number of Covid-19 cases

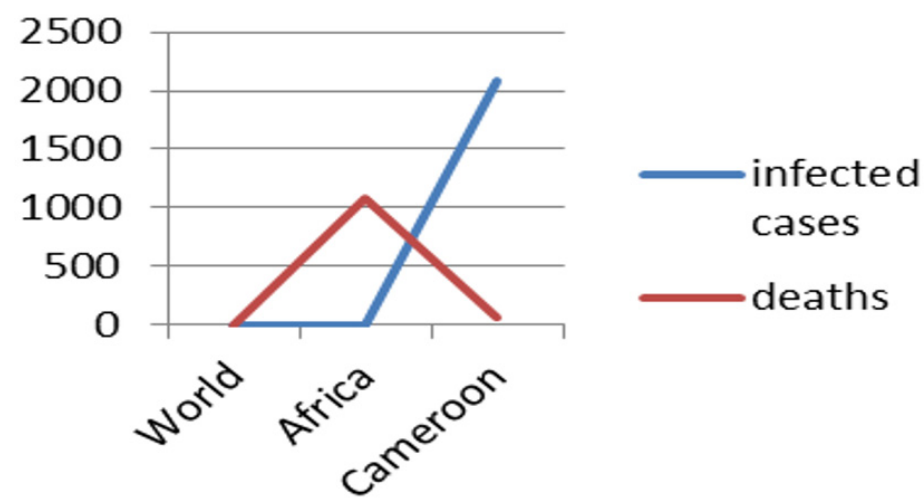

Figure 1. The trend of Covid-19 cases

Source: WHO (May 4, 2020)

Since health is a factor that improves the quality of life and well-being of people and, the outcomes of society, and considering that welfare is multidimensional rather than singularly focused on household income, we design a framework that explains how Covid-19 can affect household welfare. To better explain how Covid-19 can affect welfare, we identify two channels; the direct and the indirect channels that affect the different dimensions of welfare (figure 2). 
For the direct channel, COVID-19 can directly affect the household welfare in two ways; by death and by psychological trauma. By death, COVID-19 death is a death resulting from a clinically compatible illness in a probable or confirmed COVID-19 case (WHO, 2020). The death of family member degrades the well-being of the rest of the members in the sense that the deceased reduces the income and other advantages that were coming in through him/her and the situation is even worse if such was the breadwinner of the household, especially with the view that the disease is imported from the west by those who went in search of an object or another. Once there is a death of Covid-19 from a particular household, the rest of the surviving members witness social trauma. First, because they have to be cut off the rest of the society for at least 14 days and secondly because they lose friendship in the society since individuals now start avoiding any direct contact with them. All of this causes them to be psychologically traumatized.

Table B and Figure 2 Frequency and percentage of reduction of household welfare by COVID-19.

\section{COVID 19 WILL REDUCE WELFARE}

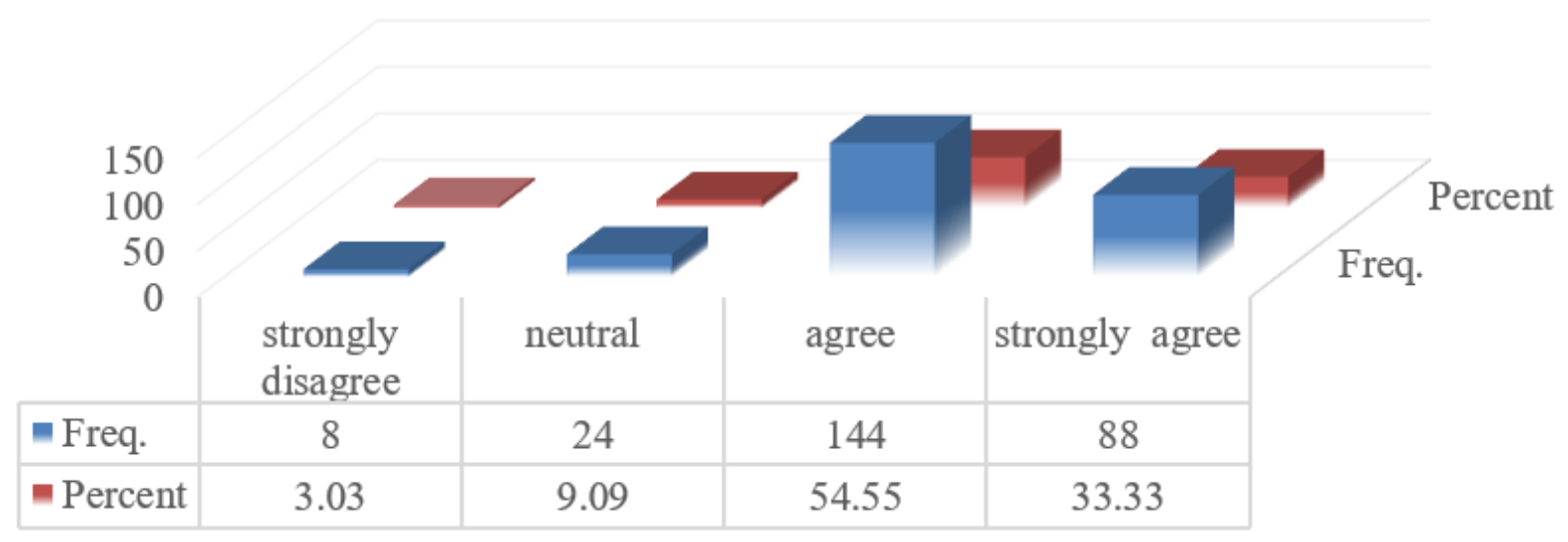

Figure. 2

Source: Authors' conception using survey data on Stata 14.

Table B and Figure 2 above show that 232 households out of 264 (87. 88\%) agreed, 8 (3.03\%) disagreed while 24 households $(9.09 \%)$ were neutral on the fact that COVID-19 could reduce welfare.

For the indirect channels, Covid-19 has caused increase difficulties in accessing basic social services such as health and education and this has created a vacuum for social inequality and low human capital to aggravate the situation. Also, businesses have been halted thereby increasing unemployment and reducing household income and by extension household consumption. So, the fight against Covid-19 is also a fight to ensure the development of human capital, growth, employment, and increased productivity. These elements and more are discussed in the subsequent paragraphs.

Worthy of note is the fact that education increases technical efficiency in production. That is, only educated people are able to produce a better or use fewer inputs to produce a larger output. Also, that is why it is often said better access to education is the key to the next generation's ability to escape from poverty or increase welfare. Therefore, Covid-19 is hampering the growth of household welfare and laying the foundation for future poverty.

On a second note, Covid-19 has come to increase household expenses on health. This is because individuals now have the burden of purchasing from time to time the hygienic materials edited by the WHO in like of follow W.O.M.E.N which stands for: wash your hands, observing social distancing, move away from crowded places, exercise regularly and no hands shaking and many others like hand sanitizers, face masks, and soap for the frequent washing of hands. This will no doubt increase household health but it requires a cost and at a moment where the population is quarantined, the cost is non-negligible and thus has an effect on household welfare.

In addition, the employment market has found itself at a dilemma on the effects of the pandemic. On the one hand, the business has been halted and workers sent on technical unemployment. This has reduced household income and as a result, reduced their consumption, especially considering that there is a somewhat rise in prices due to excess demand without little or no production. On the other hand, it is the creation of employment for businesses 
in the health sector like the production and sales of hand sanitizers, face masks, soap, buckets, COVID-19 test kids, medical gadgets, and what have you. The production and sales of these items are on the boom and one can be tempted to say Covid-19 has brought not only bad but good also.

As if that is not enough, Covid-19 has also increased both social and income inequality. For social inequality it can be observed that the distance education or e-learning imposed by the pandemic has unfavorable consequences on individuals in most parts of the developing world in general and Cameroon in particular, where there exist problems of network, no electricity and frequent light failure which it is, difficulties of possessing an android phone and most importantly a very challenging cost of accessing the internet, little wonder why the rate of internet penetration was still 30\% as at January 2020 in Cameroon (Business in Cameroon, 2020). This cost is only affordable by the privileged persons and in a country mostly made up of poor people, it contributes to reducing the wellbeing of households.

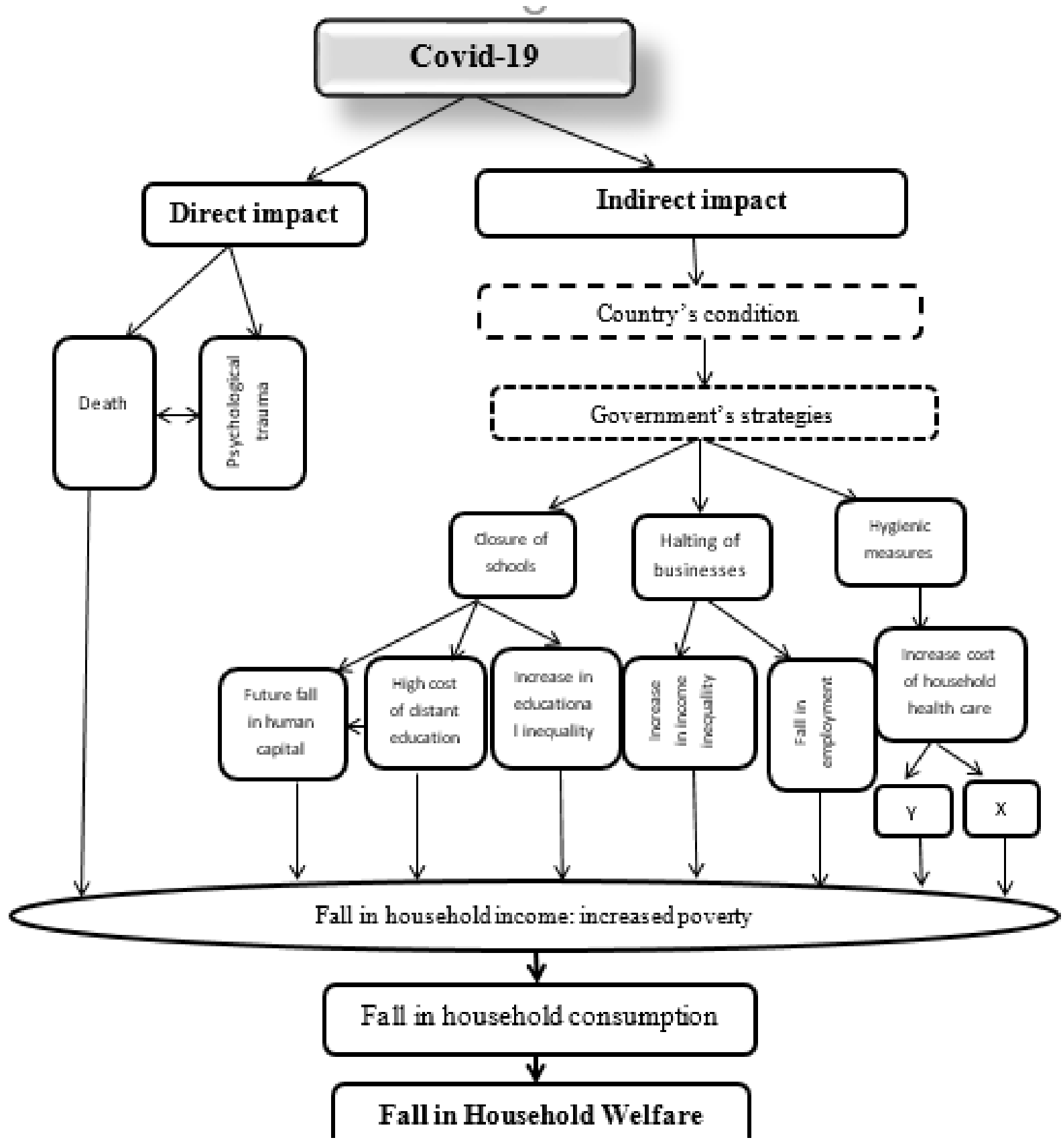

Figure 3. The Conceptual Framework of Covid-19 and Household welfare

Source: Authors (2020) 
Note: $\mathrm{X}$ represents the cost of treatment (running nose, fever, high temperatures, itching throat, breeding difficulties) and $\mathrm{Y}$ represents the cost of purchase of hand sanitizers, face masks, soap, and others

Similarly, COVID-19 has not only created a reduction in household income but it has also aggravated income inequality depending on the country. This is because pandemics rarely affect everybody in the same way. This is why some high-income countries such as the UK and the USA have engaged in employment safeguards, uncertainty looms for low-income groups and other measures. In Cameroon for example income equality in times of Covid-19 is observed between workers in the public sector who continue to perceive their salaries hitch-free and those in the private sector whose salaries have been suspended. This has contributed to degrading the wellbeing situation of the privately employed, while that of the civil-servant stay a little stable. Finally, the poor populations which already lack access to health services in normal circumstances are now left most vulnerable during this pandemic.

\subsection{Theoretical Literature}

The standard approach for assessing credit risk under Basel III depends on ratings assigned by credit rating agencies

\subsubsection{The Triple Helix Theory}

This theory generates technological innovations in three different institutionally defined spheres; university, industry, and government. This technology serves as an interface for the growth of an economy by intensifying the institutionalization of wealth creation. The dynamic interactions among university, industry, and government in the form of playing the role of the other in order to foster entrepreneurship, innovation, and economic growth is a call for concern in times of crisis like the current outbreak of Covid-19. It means that this pandemic has created knowledge on how cooperation between businesses and the population can continue to subsist without immediate contact. And also, how the public authorizes can use new instruments to support the functioning of the economy, without leaving out universities who have designed different strategies to encourage distant learning and continue to build human capital.

\subsubsection{The SIR-Model}

The pioneer theory on Covid-19 emanates from Wang et al. (2020) who developed the SIR model. This model which uses time-series data of infected COVID-19 cases and susceptible transmission mechanism, has been widely applied to the current outbreak and supposes that the exposed population were not infectious, which may imply that the vulnerable household could be left untouched. This theory provides the groundwork from which much other critical thinking has later developed such as the extended SIR (eSIR) model of Yao and Liu (2020), the SEIR model of Tang et al. (2020) and the extended SEIR model of Wu et al. (2020). The extended SIR model, for example, covers the effects of different epidemic prevention measures in different periods thereby considering the time-varying parameters which were not considered in the initial model (the SIR model). Just as the pandemic is getting to climax, theories on its outcome are still being developed and much is expected to be seen in the nearest future.

\subsection{Empirical Literature}

While some countries have been able to effectively treat reported cases, it is uncertain where and when other new cases will emerge. It is paramount to understand the macroeconomic costs of diseases in other to see the gravity of the situation and aid policymakers to globally-coordinate policy responses to tame the virus. That is to say. the experience from these previous disease outbreaks like HIV/AIDS should provide valuable evidence on the economic implications of COVID-19. According to some health scientists, the COVID-19 outbreak was caused by the SARS-COV-2 virus whose epicenter was in China. Not only is the disease spreading rapidly across the world but also the economic difficulties attached to it should be apprehensible.

To begin, Meltzer et al. (1999) was amongst the very first economists to examine the likely economic effects of the influenza pandemic in the US-economy and found that 89000 to 207000 people were killed by the influenza disease and it costed the USA an economic loss estimated at \$73.1- \$166.5 billion. Still, in line with the same disease, Bloom et al. (2005) used an Oxford economic forecasting model to estimate the potential economic impact of the pandemic on the Asian economies and concluded that a longer outbreak will lead to larger shock on consumption and export, and that open economies are more vulnerable to international shocks since the exports of these countries witness a loss of $\$ 282.7$ billion (6.5\% of GDP) and a fall in the global trade of about $\$ 2.5$ trillion (14\% of GDP).

The assessment of risks and economic impact of these pandemics depend on the probability of death and the number of lives lost. The influenza virus was far more contagious than HIV and was ranked the third leading 
probable cause of death due to its cardiovascular nature (Viscusi et al., 1997). However, apart from the Spanish influenza pandemic (the "deadliest plague in the history of pandemics), it is feared that the COVID-19 virus is very contagious than the first two and therefore may also have heavy economic repercussions. This is reflected by the response to the pandemic; closure of schools, borders and some cities, travel restrictions and banned by some countries, and the rest.

\section{Methodology and Data}

\subsection{Methodology}

To evaluate the impact of COVID-19 on household welfare, we used the classic Card and Krueger model (1994) approach to analyse the data. This is, an attempt to isolate the direct impact of COVID-19 on household welfare in Cameroon. Two alternate specifications are commonly used in the literature on impact evaluation which are written as follows:

$$
\begin{gathered}
H H W_{t}=\alpha_{0}+\alpha_{1} \text { COVID_19 } t+u_{1} \\
H H W_{t}=\beta_{0}+\beta_{1} \text { COVID_19 } 19_{t}+\sum_{i=2}^{7} \beta_{i} S_{t}+\sum_{i=8}^{n} \beta_{i} X_{t}+u_{2}
\end{gathered}
$$

Where $H H W_{t}$ is a matrix of consumption, unemployment, and poverty and $S_{t}$ is a set of variables that stands for the determinants of covid-19 (running nose, on and off fever, high temperatures, itching throat, breeding difficulties, medical report) and $X_{t}$ are control variables (age, government policy, the impression of the disease, age and propaganda, sex, a disease for travelers), $\alpha_{i}$ and $\beta_{i}$ are parameters and $u_{1}$ and $u_{2}$ stand for the respective error terms of equation 1 and 2 .

\section{Correcting for Sample Selection-bias using Heckman (1979) Approach}

The COVID-19 indicators included in the household welfare function are endogenous since the individuals are not randomly selected with different symptoms. We have accounted for this sample selection problem using the method proposed by (Heckman, 1979) which is an appropriate method to estimate the endogenous treatment effect model.

$$
\text { COVID_19 }=\gamma_{0}+\sum_{\mathrm{i}=1}^{\mathrm{n}} \gamma_{\mathrm{i}} \mathrm{S}_{\mathrm{t}}+\mathrm{u}_{3}
$$

Where $\gamma_{i}$ are parameters to be estimated, and $\mathrm{U}_{\mathrm{i}}$ represents the error terms.

$$
\mathrm{P}(\text { COVID_19 } \mathrm{t}=1 / \mathrm{S})=\Psi\left(\gamma_{0}+\sum_{\mathrm{i}=1}^{\mathrm{n}} \gamma_{\mathrm{i}} \mathrm{S}_{\mathrm{t}}\right)
$$

Where $\boldsymbol{\Psi}$ is a response probability generating function taking on values strictly between zero and one. $\mathbf{0} \leq \boldsymbol{\Psi}(\mathbf{S})$ $\leq 1$, for all real numbers $\mathrm{S}$. This ensures that the estimated response probabilities are strictly between zero and one.

From the estimates of the Probit model in Equation 4, we predict a Probit Density Function (PDF) and Cumulative Probit Density Function(CDF). Dividing the probability density function by the cumulative density function gives the respective inverse Mills ratio according to Heckman (1979). Consider that vector $\lambda$ denotes the inverse Mills ratio, the inverse mills ratio is gotten as follows:

$$
\lambda=\frac{\varphi(P D)}{\phi(P D)}
$$

$\varphi$ is the standard normal density function and $\phi$ is the standard normal distribution function.

The inverse Mills ratio, is estimated and is included among the explanatory variables of the household welfare equation.

$$
\begin{gathered}
H H W_{t}=\boldsymbol{u}_{0}+\boldsymbol{u}_{1} \text { COVID_19 }+\boldsymbol{\eta} * \lambda_{\boldsymbol{t}}+v_{1} \\
H H W_{t}=\pi_{0}+\pi_{1} \text { COVID_1 }_{-} 9_{t}+\sum_{t=2}^{6} \pi_{t} S_{t}+\sum_{t=7}^{n} \pi_{t} X_{t}+\boldsymbol{\eta} * \lambda_{t}+v_{2}
\end{gathered}
$$

Where $H H W_{t}$ is a matrix of consumption, unemployment, and poverty and $S_{t}$ is a set of variables that stands for the determinants of covid-19 (running nose, on and off fever, high temperatures, itching throat, breeding difficulties, medical report) and $X_{t}$ are control variables (age, government policy, the impression of the disease, propaganda, sex and disease for travelers), $\boldsymbol{u}_{t}, \boldsymbol{\eta}$ and $\pi_{t}$ are the parameters, $v_{1}$ and $v_{2}$ are the error terms.

\subsection{Data Set and Variables}

The dataset for the study was gotten from 264 households in Cameroon using a questionnaire. The survey was aimed at having information on COVID-19 and household welfare in Cameroon. The questionnaire was structured into four sections. Section A was the demographic information of the respondents, section B were the indicators of COVID-19, household welfare indicators were in section C and the link between COVID-19 and household welfare was in section $\mathrm{D}$. 
Table 1 below gives a summary of the different variables selected for the study and their natures.

Table 1. Nature of the variables used for the study

\begin{tabular}{|c|c|c|}
\hline Variables & Nature & Description \\
\hline Household Welfare & Dependent & It is derived from consumption, employment, and poverty \\
\hline Consumption & Dependent & $\begin{array}{l}\text { It is the portion that was set aside for food and the drop in the } \\
\text { consumption habit of the household }\end{array}$ \\
\hline Employment & Dependent & The number of persons that had jobs \\
\hline Poverty & Dependent & $\begin{array}{l}\text { Agreeing or disagreeing whether COVID-19 is another calamity to } \\
\text { deepen poverty and was between } 1 \text { to } 5 \text { in the Likert scale }\end{array}$ \\
\hline COVID-19 & Independent & COVID- $19=1$ if COVID- 19 was a reality and $0=$ if not \\
\hline Running nose & Independent & $\begin{array}{l}\text { Agreeing or disagreeing weather Running nose was a sign of } \\
\text { COVID-19 and was between } 1 \text { to } 5 \text { in the Likert scale }\end{array}$ \\
\hline Itching throat & Independent & $\begin{array}{l}\text { Agreeing or disagreeing whether Itching throat was a sign of } \\
\text { COVID- } 19 \text { and was between } 1 \text { to } 5 \text { in the Likert scale }\end{array}$ \\
\hline Breeding difficulties & Dependent & $\begin{array}{l}\text { Agreeing or disagreeing whether Breeding difficulties was a sign of } \\
\text { COVID-19 and were between } 1 \text { to } 5 \text { in the Likert scale }\end{array}$ \\
\hline On and off fever & Dependent & $\begin{array}{l}\text { Agreeing or disagreeing weather On and off fever was a sign of } \\
\text { COVID-19 and was between } 1 \text { to } 5 \text { in the Likert scale }\end{array}$ \\
\hline High temperature & Independent & $\begin{array}{l}\text { Agreeing or disagreeing weather High temperature was a sign of } \\
\text { COVID-19 and was between } 1 \text { to } 5 \text { in the Likert scale }\end{array}$ \\
\hline Gender & Independent & Gender $=1$ if male and 0 if not \\
\hline Age & Independent & This is the number of years of the respondent in the household \\
\hline Propaganda & Independent & $\begin{array}{l}\text { Agreeing or disagreeing whether COVID-19 is a propaganda and } \\
\text { was between } 1 \text { to } 5 \text { in the Likert scale }\end{array}$ \\
\hline Chinese virus & Independent & $\begin{array}{l}\text { Agreeing or disagreeing whether COVID-19 is a Chinese virus and } \\
\text { was between } 1 \text { to } 5 \text { in the Likert scale }\end{array}$ \\
\hline Disease of travelers & Independent & $\begin{array}{l}\text { Agreeing or disagreeing whether COVID-19 is a disease for those } \\
\text { travelers and was between } 1 \text { to } 5 \text { in the Likert scale }\end{array}$ \\
\hline Government strategy & Independent & $\begin{array}{l}\text { Agreeing or disagreeing whether government strategy can cure } \\
\text { COVID- } 19 \text { and was between } 1 \text { to } 5 \text { in the Likert scale }\end{array}$ \\
\hline
\end{tabular}

Source: Authors' conception using survey data on Stata 14

\section{Presentation and Discussion of Results}

\subsection{Descriptive Statistics}

Descriptive statistics of the survey dataset showed that the mean value of the household welfare is 19.12 . The minimum value of household welfare is 7 , while the maximum is 27 with a standard deviation of 4.33 . The mean value of poverty is 3.97. the minimum value of poverty is 1 , while the maximum is 5 with a standard deviation of 1.32. Also, the mean value of consumption is 8.18 ; the minimum value was 4 , while the maximum was 16 with a standard deviation of 3.04. Statistics equally showed that the mean value of employment is 6.97 with a minimum value of 2 and a maximum value of 10 with a standard deviation of 2.25 . Furthermore, the results showed that the mean value of COVID-19 is 0.33 with a minimum value of 0 and a maximum value of 1 with a standard deviation of 0.47 . 
Table 2. Descriptive Statistics

\begin{tabular}{lcllll}
\hline Variable & Obs & Mean & Std. Dev. & Min & Max \\
\hline Household Welfare & 264 & 19.12 & 4.33 & 7 & 27 \\
Consumption & 264 & 8.18 & 3.04 & 4 & 16 \\
Employment & 264 & 6.97 & 2.25 & 2 & 10 \\
Poverty & 264 & 3.97 & 1.32 & 1 & 5 \\
Covid-19 & 264 & 0.33 & 0.47 & 0 & 1 \\
Running nose & 264 & 3.67 & 1.07 & 1 & 5 \\
Itching throat & 264 & 3.73 & 0.99 & 1 & 5 \\
Breeding difficulties & 264 & 4.09 & 1.03 & 1 & 5 \\
On and off fever & 264 & 3.36 & 1.20 & 1 & 5 \\
High temperature & 260 & 3.62 & 1.13 & 1 & 5 \\
Gender & 264 & 0.52 & 0.50 & 0 & 1 \\
Age & 264 & 27.70 & 7.26 & 12 & 43 \\
Propaganda & 264 & 2.58 & 1.10 & 1 & 5 \\
Chinese virus & 264 & 3.30 & 1.27 & 1 & 5 \\
Disease of travelers & 264 & 3.15 & 1.16 & 1 & 5 \\
Calamity for poverty & 264 & 3.88 & 1.04 & 1 & 5 \\
Government strategy & 264 & 2.88 & 1.28 & 1 & 5 \\
Inverse mills & 260 & 1.11 & 0.26 & 0.63 & 1.71 \\
\hline
\end{tabular}

Source: Authors' conception using survey data on Stata 14

\section{Correlation between COVID-19 and household welfare}

From the Pearson correlation table 3 below, we realize that the COVID-19 has a negative relationship with household welfare in Cameroon.

Table 3. Correlations

\begin{tabular}{|c|c|c|c|c|c|c|}
\hline & & COVID-19 & Consumption & Employment & Household welfare & Poverty \\
\hline \multirow[t]{3}{*}{ COVID-19 } & Pearson Correlation & 1 & $-.297^{* *}$ & $-.362^{* *}$ & $-.377^{* *}$ & .065 \\
\hline & Sig. (2-tailed) & & .000 & .000 & .000 & .291 \\
\hline & $\mathrm{N}$ & 264 & 264 & 264 & 264 & 264 \\
\hline \multirow[t]{3}{*}{ consumption } & Pearson Correlation & $-.297^{* *}$ & 1 & .116 & $.677^{* *}$ & $-.280^{* *}$ \\
\hline & Sig. (2-tailed) & .000 & & .059 & .000 & .000 \\
\hline & $\mathrm{N}$ & 264 & 264 & 264 & 264 & 264 \\
\hline \multirow[t]{3}{*}{ Employment } & Pearson Correlation & $-.362^{* *}$ & .116 & 1 & $.774^{* *}$ & $.564^{* *}$ \\
\hline & Sig. (2-tailed) & .000 & .059 & & .000 & .000 \\
\hline & $\mathrm{N}$ & 264 & 264 & 264 & 264 & 264 \\
\hline \multirow[t]{3}{*}{ Household welfare } & Pearson Correlation & $-.377^{* *}$ & $.677^{* *}$ & $.774^{* *}$ & 1 & $.401^{* *}$ \\
\hline & Sig. (2-tailed) & .000 & .000 & .000 & & .000 \\
\hline & $\mathrm{N}$ & 264 & 264 & 264 & 264 & 264 \\
\hline \multirow[t]{3}{*}{ Poverty } & Pearson Correlation & .065 & $-.280^{* *}$ & $.564^{* *}$ & $.401^{* *}$ & 1 \\
\hline & Sig. (2-tailed) & .291 & .000 & .000 & .000 & \\
\hline & $\mathrm{N}$ & 264 & 264 & 264 & 264 & 264 \\
\hline
\end{tabular}

**. Correlation is significant at the 0.01 level (2-tailed).

Source: Authors' conception using survey data on Stata 14

In a more precise manner, we deduce that the correlation between COVID-19 and poverty in Cameroon is positive and insignificant, with $\mathrm{r}=0.065$, the correlation between COVID-19 and consumption is negative and significant, 
with $\mathrm{r}=-0.297$ at $1 \%$ level, the correlation between COVID-19 and employment is negative and significant, with $\mathrm{r}$ $=-0.362$ at $1 \%$ level and the correlation between COVID-19 and household welfare is negative and significant, with $r=-0.377$ at $1 \%$ level. These results imply that COVID-19 and its variables have a negative relationship on household welfare in Cameroon. From the Pearson Correlation results, we proceed to the econometric regression in order to verify the impact of COVID-19 on household welfare, which will permit us to measure in a precise manner the contribution of the COVID-19 variables on poverty and household welfare in Cameroon.

\subsection{Capturing the Impact of COVID-19 on Household Welfare Using Linear Regression}

From the regression, we present the impact of each of the different dimensions of COVID-19 variables on household welfare in Cameroon.

\subsubsection{Simple Linear Regression Analysis}

Table 4. Simple Linear Regression Estimate

\begin{tabular}{lcccc}
\hline Variables & Consumption & Poverty & Employment & overall OLS \\
\hline COVID-19 & $-1.909^{* * *}$ & $0.636^{* * *}$ & $-1.727^{* * *}$ & $-3.455^{* * *}$ \\
& $(0.374)$ & $(0.199)$ & $(0.301)$ & $(0.632)$ \\
Constant & $8.818^{* * *}$ & $4 * * *$ & $7.545^{* * *}$ & $20.27^{* * *}$ \\
& $(0.222)$ & $(0.0884)$ & $(0.142)$ & $(0.224)$ \\
Observations & 264 & 264 & 264 & 264 \\
R-squared & 0.088 & 0.047 & 0.131 & 0.142 \\
\hline
\end{tabular}

Robust standard errors in parentheses

*** $\mathrm{p}<0.01, * * \mathrm{p}<0.05, * \mathrm{p}<0.1$

Source: Authors' conception using survey data on Stata 14

From the table 4 regression results, COVID-19 exerts a negative impact on consumption with a regression coefficient of -1.909 of equation 1. This implies that a unit variation in COVID-19 will lead to a decrease in household consumption by 1.909 . The results also show that COVID-19 exhibits a positive impact on poverty with a coefficient of 0.636 of equation 1, implying that a unit variation in COVID-19 will lead to an increase in household poverty by $0.636(63.6 \%)$. Further, the results show that COVID-19 exerts a negative impact on employment with a coefficient of -1.727 of equation 1, implying that a unit variation in COVID-19 will lead to a decrease on employment by 1.727. Finally, the results show that COVID-19 exerts a negative impact on household welfare with a regression coefficient of -3.455 of equation 1, implying that a unit variation in COVID-19 will lead to a decrease in household welfare by 3.455 .

\subsubsection{Multiple Linear Regression Analysis}

From the ordinary least square regression, we proceed to present the impact of each of the different dimensions of COVID-19 variables on household welfare.

Table 5. Multiple Linear Regression Estimates

\begin{tabular}{lllll}
\hline & $(1)$ & $(2)$ & $(3)$ & $(4)$ \\
Variables & Consumption & Poverty & Employment & Household welfare \\
\hline COVID-19 & $-1.216^{* * *}$ & $0.355^{* *}$ & $-1.512^{* * *}$ & $-2.320^{* * *}$ \\
& $(0.414)$ & $(0.175)$ & $(0.259)$ & $(0.569)$ \\
Running nose & $-1.990^{* * *}$ & 0.185 & $0.816^{* *}$ & $-1.240^{*}$ \\
& $(0.720)$ & $(0.350)$ & $(0.406)$ & $(0.639)$ \\
Itching throat & $2.019^{* * *}$ & $0.697^{* * *}$ & $0.890^{* * *}$ & $3.764^{* * *}$ \\
& $(0.426)$ & $(0.243)$ & $(0.298)$ & $(0.497)$ \\
Breeding difficulties & $1.020^{* * *}$ & $0.541^{* * *}$ & $0.405^{* *}$ & $2.078^{* * *}$ \\
& $(0.304)$ & $(0.162)$ & $(0.188)$ & $(0.308)$ \\
On and off fever & $-1.035^{* * *}$ & $-0.575^{* * *}$ & $-1.590^{* * *}$ & $-3.141^{* * *}$ \\
& $(0.361)$ & $(0.130)$ & $(0.184)$ & $(0.431)$
\end{tabular}




\begin{tabular}{lllll} 
High temperature & $0.882^{* * *}$ & $-0.267^{* *}$ & $0.528^{* * *}$ & $1.111^{* * *}$ \\
Gender & $(0.244)$ & $(0.104)$ & $(0.111)$ & $(0.214)$ \\
& $-2.171^{* * *}$ & $-0.427^{*}$ & 0.130 & $-2.506^{* * *}$ \\
Age & $(0.450)$ & $(0.218)$ & $(0.285)$ & $(0.605)$ \\
& $0.0519^{*}$ & $0.0282^{* *}$ & $0.0889^{* * *}$ & $0.168^{* * *}$ \\
Propaganda & $(0.0304)$ & $(0.0134)$ & $(0.0208)$ & $(0.0441)$ \\
& 0.248 & 0.149 & $0.873^{* * *}$ & $1.270^{* * *}$ \\
Chinese virus & $(0.207)$ & $(0.104)$ & $(0.127)$ & $(0.293)$ \\
& -0.203 & $-0.579^{* * *}$ & $-0.632^{* * *}$ & $-1.373^{* * *}$ \\
Disease for travelers & $(0.211)$ & $(0.105)$ & $(0.137)$ & $(0.293)$ \\
& $0.706^{* * *}$ & 0.0353 & $-0.301^{* *}$ & 0.444 \\
Government strategy & $(0.230)$ & $(0.0801)$ & $(0.146)$ & $(0.295)$ \\
& $-0.311^{* * *}$ & $0.282^{* * *}$ & 0.104 & 0.102 \\
Constant & $(0.113)$ & $(0.0664)$ & $(0.0978)$ & $(0.183)$ \\
& $2.342^{*}$ & $1.273^{*}$ & 0.868 & $4.585^{* *}$ \\
Observations & $(1.193)$ & $(0.655)$ & $(0.990)$ & $(1.959)$ \\
R-squared & 260 & 260 & 260 & 260 \\
\hline
\end{tabular}

Robust standard errors in parentheses

$* * * \mathrm{p}<0.01, * * \mathrm{p}<0.05,{ }^{*} \mathrm{p}<0.1$

Source: Authors' conception using survey data on Stata 14

From the multiple regression results of table 5, COVID-19 exerts a negative impact on consumption with a coefficient of -1.216 of equation 2, implying that a unit variation in COVID-19 leads to a decrease in the household consumption by 1.216 . The regression results also show that COVID-19 exerts a positive impact on poverty with a coefficient of 0.355 of equation 2, meaning that a unit variation in COVID-19 brings about an increase in the household poverty of $0.355(35.5 \%)$. Equally, the results show that COVID-19 exerts a negative impact on employment with a coefficient of -1.512 of equation 2, stipulating that a unit variation in COVID-19 leads to a decrease on employment by 1.512. Finally, the results show that COVID-19 exerts a negative impact on household welfare with a regression coefficient of -2.320 of equation 2 , which means a unit variation in COVID-19 leads to a decrease in household welfare by 2.320 .

Table 6. Major symtoms of COVID-19 using a probit model

\begin{tabular}{lll}
\hline Variables & Probit coefficients & Marginal effects \\
\hline Running nose & $1.007^{* * *}$ & $0.297^{* * *}$ \\
Itching throat & $(0.365)$ & $(0.107)$ \\
& $-1.227^{* * *}$ & $-0.362^{* * *}$ \\
Breeding difficulties & $(0.307)$ & $(0.0845)$ \\
On and off fever & $-0.393^{* *}$ & $-0.116^{* *}$ \\
& $(0.157)$ & $(0.0451)$ \\
High temperature & $0.463^{* *}$ & $0.137^{* *}$ \\
& $(0.217)$ & $(0.0612)$ \\
Gender & $0.230^{*}$ & $0.0680^{*}$ \\
& $(0.120)$ & $(0.0348)$ \\
Age & $-0.393^{*}$ & $-0.116^{*}$ \\
& $(0.237)$ & $(0.0698)$ \\
Propaganda & -0.0149 & -0.00440 \\
& $(0.0167)$ & $(0.00492)$ \\
Chinese virus & $-0.411^{* * *}$ & $-0.121^{* * *}$ \\
Disease for travelers & $(0.106)$ & $(0.0283)$ \\
& $0.254^{* *}$ & $0.0750^{* *}$ \\
& $(0.114)$ & $(0.0323)$ \\
& $-0.487^{* * *}$ & $-0.144^{* * *}$ \\
& $(0.120)$ & $(0.0313)$
\end{tabular}




\begin{tabular}{lll} 
Government strategy & -0.00383 & -0.00113 \\
& $(0.0712)$ & $(0.0210)$ \\
Constant & $1.951^{* * *}$ & \\
& $(0.636)$ & 260 \\
\hline
\end{tabular}

Robust standard errors in parentheses

$* * * \mathrm{p}<0.01,{ }^{* *} \mathrm{p}<0.05,{ }^{*} \mathrm{p}<0.1$

Source: Authors' conception using survey data on Stata 14

From the Probit regression results, the major symptoms of COVID-19 include; running nose, on and off fever and high temperature and have positive marginal effect while itching throat and breeding difficulties are also major determinants of COVID-19 but have reducing marginal effect.

4.3 Capturing the Impact of COVID-19 on Household Welfare Using Heckman Sample Selection Bias Approach

From the Regression results above, we present the impact of COVID 19 on household welfare using the Heckman sample selection approach.

Table 7. Impact of COVID-19 on Household welfare using Heckman sample selection bias Approach without control variables

\begin{tabular}{lcccc}
\hline Variables & Consumption & Poverty & Employment & Household welfare \\
\hline \multirow{2}{*}{ COVID-19 } & & & & \\
& $-1.636^{* * *}$ & $0.380^{* *}$ & $-1.729^{* * *}$ & $-2.985^{* * *}$ \\
Inverse mill ratio & $(0.389)$ & $(0.167)$ & $(0.293)$ & $(0.609)$ \\
& $1.978^{* * *}$ & $1.270^{* * *}$ & -0.434 & $2.815^{* * *}$ \\
Constant & $(0.637)$ & $(0.320)$ & $(0.450)$ & $(0.799)$ \\
& $6.523^{* * *}$ & $2.413^{* * *}$ & $7.991^{* * *}$ & $16.93^{* * *}$ \\
Observations & $(0.802)$ & $(0.388)$ & $(0.532)$ & $(1.010)$ \\
R-squared & 260 & 260 & 260 & 260 \\
\hline
\end{tabular}

Robust standard errors in parentheses

$* * * \mathrm{p}<0.01, * * \mathrm{p}<0.05, * \mathrm{p}<0.1$

Source: Authors' conception using survey data on Stata 14

From the regression results, COVID-19 exerts a negative impact on consumption with a regression coefficient of -1.636 of equation 3, implying that a unit variation in COVID-19 will lead to a decrease in household consumption by 1.636 . The results also show that COVID-19 has a positive impact on poverty with a regression coefficient of 0.380 of equation 3, implying that a unit variation in COVID-19 leads to an increase in the household poverty by $0.380(38.0 \%)$. Again, the results show that COVID-19 contributes a negative impact on employment with a regression coefficient of -1.729 of equation 2, implying that a unit variation in COVID-19 leads to a decrease on the employment level by 1.729. Finally, the results show that COVID-19 exerts a negative impact on household welfare with a regression coefficient of -2.985 of equation 2, portraying that a unit variation in COVID-19 will lead to a decrease in household welfare by 2.985 .

Table 7. Impact of COVID-19 on Household welfare using Heckman sample selection bias approach with control variables

\begin{tabular}{lllll}
\hline Variables & Consumption & Poverty & Employment & Household welfare \\
\hline COVID-19 & $-0.848^{*}$ & 0.233 & $-1.784^{* * *}$ & $-2.589^{* * *}$ \\
& $(0.489)$ & $(0.185)$ & $(0.279)$ & $(0.563)$ \\
\hline Running nose & $-7.831^{* * *}$ & $2.353^{* *}$ & $5.639^{* * *}$ & $4.075^{* * *}$
\end{tabular}




\begin{tabular}{lllll} 
& $(2.506)$ & $(1.076)$ & $(1.494)$ & $(1.327)$ \\
\hline Itching throat & $9.273^{* * *}$ & -2.056 & $-5.234^{* * *}$ & $-2.684^{* *}$ \\
& $(3.197)$ & $(1.352)$ & $(1.818)$ & $(1.213)$ \\
\hline Breeding difficulties & $3.331^{* * *}$ & -0.312 & $-1.493^{* * *}$ & 0.0873 \\
& $(0.954)$ & $(0.422)$ & $(0.566)$ & $(0.414)$ \\
\hline On and off fever & $-3.726^{* * *}$ & 0.492 & 0.784 & $-0.623^{*}$ \\
& $(1.244)$ & $(0.557)$ & $(0.679)$ & $(0.323)$ \\
\hline High temperature & -0.513 & 0.262 & $1.704^{* * *}$ & $2.256^{* * *}$ \\
& $(0.632)$ & $(0.265)$ & $(0.327)$ & $(0.221)$ \\
\hline Gender & -0.115 & $-1.239^{* * *}$ & $-1.677^{* * *}$ & $-3.997^{* * *}$ \\
& $(0.985)$ & $(0.337)$ & $(0.564)$ & $(0.768)$ \\
\hline Age & $0.157^{* * *}$ & -0.0129 & -0.00248 & \\
& $(0.0588)$ & $(0.0264)$ & $(0.0319)$ & \\
\hline Propaganda & $2.567^{* *}$ & $-0.751^{*}$ & $-1.128^{*}$ & $-0.860^{* *}$ \\
& $(1.048)$ & $(0.420)$ & $(0.584)$ & $(0.355)$ \\
\hline Chinese virus & $-1.670^{* *}$ & 0.00551 & $0.669^{*}$ & \\
& $(0.728)$ & $(0.336)$ & $(0.402)$ & \\
\hline Disease for travelers & $3.296^{* * *}$ & $-0.968^{*}$ & $-2.533^{* * *}$ & $-1.937^{* * *}$ \\
& $(1.178)$ & $(0.499)$ & $(0.640)$ & $(0.429)$ \\
\hline Government strategy & $-0.275^{* *}$ & $0.278^{* * *}$ & 0.0968 & 0.152 \\
& $(0.107)$ & $(0.0624)$ & $(0.0911)$ & $(0.178)$ \\
\hline Inverse mill ratio & $-7.507^{* *}$ & $2.912^{* *}$ & $6.478^{* * *}$ & $6.739^{* * *}$ \\
& $(3.163)$ & $(1.409)$ & $(1.900)$ & $(1.266)$ \\
\hline Constant & -2.535 & $3.204^{* * *}$ & $5.164^{* * *}$ & $10.34^{* * *}$ \\
& $(2.829)$ & $(1.049)$ & $(1.509)$ & $(1.502)$ \\
\hline Observations & 260 & 260 & 260 & 260 \\
R-squared & 0.361 & 0.371 & 0.594 & 0.497 \\
\hline Robust stan & & & \\
\hline
\end{tabular}

Robust standard errors in parentheses

$* * * \mathrm{p}<0.01, * * \mathrm{p}<0.05, * \mathrm{p}<0.1$

Source: Authors' conception using survey data on Stata 14

From table 7, results show that COVID-19 has a negative impact on consumption with a regression coefficient of -0.848 of equation 3 . Similarly, the results show that COVID-19 has a positive impact on poverty with a regression coefficient of 0.233 of equation 3, which means a unit variation in COVID-19 will present an increase in the household poverty by $0.233(23.3 \%)$. Also, results show that COVID-19 impact negatively employment with a regression coefficient of -1.784 of equation 2, that means a unit variation in COVID-19 leads to a decrease on the employment level by 1.784. Ultimately, the results show that COVID-19 exerts a negative impact on household welfare with a regression coefficient of -2.589 of equation 2, implying that a unit variation in COVID-19 will lead to a decrease in household welfare by 2.589 .

\section{Conclusion and Policy Recommendations}

The regression results for equations 1, 2, 6 and 7 show that COVID-19 is poverty augmenting meaning that COVID-19 is a new calamity for poverty and hunger in the developing countries and Cameroon in particular. COVID-19 reduces household consumption, employment and increases unemployment in Cameroon. Finally, COVID-19 reduces household welfare. This indicates that a unit increase in the COVID-19 will lead to a decrease in household welfare by about 2.589 units. These findings have implications of reducing the impact of COVID-19 on household welfare by educating households on developing new sources of income and food strategies like engaging more on agricultural activities. Government can take another strategy of allocating grants either by reducing the cost of basic necessities (water, electricity, foodstuff, and housing). Another important strategy that should be taken into consideration is that the government, institutions of technology, and businesses should use the triple helix approach to develop a vaccine for the pandemic to bring back economic life to normal. 


\section{Acknowledgements}

Financial support for this study came from Prof. Moses A. Ofeh who equally was the academic adviser and manuscript arranger. Otherwise, every author in this paper played a leading role through the team and joint discussions under his guidance.

\section{References}

Arndt, C., \& Lewis, J. D. (2001). The HIV/AIDS Pandemic in South Africa: Sectoral Impacts and Unemployment. Journal of International Development, 13(4), 427-449. https://doi.org/10.1002/jid.796

Atkeson, A. (2020). What will be the Economic Impact of COVID-19 in the US? Rough Estimates of Disease Scenarios, National Bureau of Economic Research (NBER) Working Paper 26867, 1050 Massachusetts Avenue Cambridge. https://doi.org/10.3386/w26867

Baldwin, R., \& Weder, B. D. M. (2020). Economics in the Time of COVID-19, Centre for Economic Policy Research-CEPR Press ISBN: 978-1-912179-28-2, 33 Great Sutton Street London.

Bell, C., Devarajan, S., \& Hersbach, H. (2004). Thinking about the long-run economic costs of AIDS, in The Macroeconomics of HIV/AIDS, M. Haacker (eds). Washington DC., IMF: 96-144.

Bhargava, A., et al. (2001). Modeling the Effects of Health on Economic Growth. Journal of Health Economics 20(3), 423-440. https://doi.org/10.1016/S0167-6296(01)00073-X

Bloom, D. E., \& Sachs, J. D. (1998). Geography, Demography, and Economic Growth in Africa. Brookings Papers on Economic Activity, (2), 207-273.

Bloom, E., V. D. W., et al. (2005). Potential economic impact of an Avian Flu pandemic on Asia. ERD Policy Brief Series No. 42, Asian Development Bank, Manila. Retrieved from http://www.adb.org/Documents/EDRC/Policy_Briefs/PB042.pdf

Congressional Budget Office (CBO, 2005). A Potential Influenza Pandemic: Possible Macroeconomic Effects and Policy Issues, CBO Washington DC.

Cuddington, J. T., \& Hancock, J. D. (1994). Assessing the Impact of AIDS on the Growth Path of the Malawian Economy. Journal of Development Economics, 43(2), 363-368. https://doi.org/10.1016/03043878(94)90013-2

Cuddington, J. T., \& Hancock, J. D., et al. (1994). A Dynamic Aggregate Model of the AIDS Epidemic with Possible Policy Interventions. Journal of Policy Modeling, 16(5), 473-496. https://doi.org/10.1016/01618938(94)90024-8

Haacker, M., Ed. (2004). The Macroeconomics of HIV/AIDS. IMF, Washington DC.

Heckman, J. (1979). Sample selection bias as a specification error. Econometrica, 47(1), 153-162. https://doi.org/10.2307/1912352

International Labor Organization (ILO, 2020). COVID-19 and the world of work: Impact and policy responses. Retrieved from http://ilo.org/global/topics/coronavirus

McKibbin, W., \& Sidorenko, A. (2006). "Global Macroeconomic Consequences of Pandemic Influenza" Lowy Institute Analysis, February, 100 pages.

McKibbin, W., \& Sidorenko, A. (2009). "What a Flu Pandemic Could Cost the World", Foreign Policy, April. Retrieved from https://foreignpolicy.com/2009/04/28/what-a-flu-pandemic-could-cost-the-world/

McKibbin, W., \& Fernando, R. (2020). The Global Macroeconomic Impacts of COVID-19: Seven Scenarios, Centre for Applied Macroeconomic Analysis (CAMA) of the Australian National University Working Paper 19/2020 February 2020. https://doi.org/10.1162/asep_a_00796

Meltzer, M. I., \& Cox, N. J., et al. (1999). The economic impact of pandemic influenza in the United States: priorities for intervention. Emerging Infectious Diseases, 5(5), 659-671. https://doi.org/10.3201/eid0505.990507

OECD. (2020). OECD Economic Outlook, Interim Report March 2020, OECD Publishing. Retrieved from http://www.oecd.org/newsroom/global-economy-faces-gravest-threat-since-the-crisis-as-coronavirusspreads.htm

Robalino, D. A., \& Voetberg, A., et al. (2002b). The Macroeconomic Impacts of AIDS in Kenya Estimating Optimal Reduction Targets for the HIV/AIDS Incidence Rate. Journal of Policy Modeling, 24(2), 195-218. 
https://doi.org/10.1016/S0161-8938(02)00097-2

Robalino, D. A., \& Jenkins, C., et al. (2002a). The Risks and Macroeconomic Impact of HIV/AIDS in the Middle East and North Africa: Why Waiting to Intervene Can Be Costly. Policy Research Working Paper Series: 2874, 2002. https://doi.org/10.1596/1813-9450-2874

Tang, B., Wang, X., Li, Q., Bragazzi, N. L., Tang, S., \& Xiao, Y., et al. (2020). Estimation of the Transmission Risk of the 2019-nCoV and Its Implication for Public Health Interventions. J Clin Med., 9(2). PubMed PMID: 32046137. https://doi.org/10.3390/jcm9020462

The World Bank. (2006). Socioeconomic Impact of HIV/AIDS in Ukraine, The World Bank and the International HIV/AIDS Alliance in Ukraine and Washington D.C. Retrieved from http://siteresources.worldbank.org/INTUKRAINE/Resources/328335-1147812406770/ukr_aids_eng.pdf

United Nations Economic Commission for Africa (UNECA, 2020). Economic Impact of the COVID-19 on Africa, Addis Ababa, Ethiopia March 13, 2020.

Viscusi, W. K., \& Hakes, J. K., et al. (1997). Measures of Mortality Risks. Journal of Risk and Uncertainty, 14(3), 213-233. https://doi.org/10.1023/A:1007799508646

Wang, C., Horby, P. W., Hayden, F. G., \& Gao, G. F. (2020). A novel coronavirus outbreak of global health concern. Lancet, 395(10223), 470-473. https://doi.org/10.1016/S0140-6736(20)30185-9

WHO Commission on Macroeconomics and Health, Ed. (2001). Macroeconomics and Health: Investing in Health for Economic Development, World Health Organization.

Wu, J. T., Leung, K., \& Leung, G. M. (2020). Nowcasting and forecasting the potential domestic and international spread of the 2019-nCoV outbreak originating in Wuhan, China: A modeling study. 227 Lancet (2020). PubMed PMID: 32014114. https://doi.org/10.1016/S0140-6736(20)30260-9

Yao, H., \& Liu, M. (2020). Extended SIR prediction of the trend of the epidemic of COVID-19 in Italy and compared with Hunan, China. https://doi.org/10.1101/2020.03.18.20038570h

\section{Note}

Note 1. A pandemic is defined as a disease that is prevalent over a whole country or the world.

\section{Copyrights}

Copyright for this article is retained by the author(s), with first publication rights granted to the journal.

This is an open-access article distributed under the terms and conditions of the Creative Commons Attribution license (http://creativecommons.org/licenses/by/4.0/). 